\title{
Structure and performance of Awassi and Assaf dairy sheep farms in northwestern Spain
}

\author{
M. J. Milán, ${ }^{\star}$ G. Caja, ${ }^{\star 1}$ R. González-González,† A. M. Fernández-Pérez,‡ and X. Such* \\ *Grup de Recerca en Remugants (G2R), Universitat Autònoma de Barcelona, 08193 Bellaterra, Spain \\ †Grupo Agropal Soc. Coop., 34004 Palencia, Spain \\ $\ddagger$ Nutreco-España, 49780 Pobladura del Valle, Zamora, Spain
}

\section{ABSTRACT}

Data of 69 dairy sheep farms (70\% Assaf and 30\% Awassi crossbred), located in the Spanish Autonomous Community of Castilla y León and grouped for receiving technical advice, were used to study their structure and performance. Farm surface was 55.4 ha, on average. Approximately $25 \%$ of the farms did not have cultivation land, and the other $75 \%$ had, on average, 73 ha (from which $67 \%$ were devoted to forage). Farms used 2.1 annual work units (familiar, 90\%), 493 ewes, and yielded 147,000 L/yr of milk. Farmers were tenant (84\%), younger than $45 \mathrm{yr}(70 \%)$, had new houses, and were grouped in cooperatives (83\%). Sheep were fed indoors (occasional grazing only) in modern loose stalls and had machine milking. Planned mating (summer to fall) was done in $91 \%$ of farms (hormonal treatment, $54 \%$ ) but artificial insemination was scarce (23\%). Annual milk sales averaged $309 \mathrm{~L} /$ ewe (fat, 6.5\%; protein, $5.3 \%$; $\log _{10}$ somatic cell count, 5.7), and milk was sent to local dairy industries for cheese production, and 1.35 lambs/ewe were harvested as milk-fed lambs (lechazo). Artificial lamb rearing was done in $38 \%$ of farms (automatic, 81\%; manual, 19\%). Total mixed rations were used in $33 \%$ of farms, and the rest used rationed concentrate (including self-produced cereals) according to physiological stage of the ewes (0.45 to $1.97 \mathrm{~kg} / \mathrm{d}$ ) and ad libitum forage (dehydrated, $70 \%$; hay, $68 \%$; fresh, $25 \%$; silage, $12 \%$ ). The concentrateto-forage ratio ranged between 32 and $61 \%$. In total, $68 \%$ of farms bought more than half of the forage, and $87 \%$ of them bought more than half of the required concentrates. According to structural, productive, and managerial traits, 4 types of farms were differentiated by using multiple correspondence analysis and cluster analysis. Type groups were: 1) large-surface farms, devoted to cereal and forage production, predominantly with Awassi crossbreed sheep and a high level

Received June 9, 2010.

Accepted October 24, 2010.

${ }^{1}$ Corresponding author: gerardo.caja@uab.es of self-consumed commodities (12\% of the farms); 2) large flocks with intermediate farm surfaces devoted to forage production and predominantly with Assaf sheep (30\% of the farms); 3) high-yielding farms, with intermediate sized flocks of Assaf sheep and very intensive management ( $42 \%$ of the farms); and, 4) no-land farms predominantly with Assaf sheep (16\% of the farms). In conclusion, the dairy sheep farms studied showed more adoption of intensive production systems than traditional farms, which resulted in higher milk and lamb yields. Despite all of them being based on familiar units, as traditional farms, they were highly dependent on external resources and became more vulnerable, faced with future uncertainties of the market.

Key words: Assaf, Awassi, dairy sheep, farm typology

\section{INTRODUCTION}

Sheep milk production in Spain increased almost $30 \%$ during the last $20 \mathrm{yr}$, reaching 445 million L in 2010 (MARM, 2010). Despite this increase in milk production, the population of dairy ewes has diminished slightly, totaling approximately 2.9 million heads, which represents $16 \%$ of the total Spanish ewe population. Most dairy sheep in Spain (75\%) are located in the Autonomous Communities of Castilla y León and Castilla-La Mancha, which produced 62.0 and $28.3 \%$ of the total Spanish sheep milk in 2008, respectively (MARM, 2010). Traditional dairy sheep production systems have used local breeds (i.e., Castellana, Churra, and Manchega), exploited in semi-intensive systems and producing meat lambs and cheeses that are very appreciated in the national and international markets (Caja and de Rancourt, 2002). Traditional sheep products are, in most cases, sold under the European guaranteed labels of Protected Designation of Origin and Protected Geographical Indication, for cheeses and meat, respectively.

Although local breeds are well adapted to the local environmental conditions, they have low milk yield. Average annual milk yield of dairy sheep in Spain and in Castilla y León are 159 and 190 L, respectively (MARM, 
2010). As a response to the growing demand for sheep dairy products, and to an increase in labor costs, improved foreign breeds were introduced in the traditional dairy sheep production areas in Spain, the Awassi and Assaf being the most popular foreign breeds (Ugarte et al., 2001). Improved Awassi sheep (Epstein, 1982, 1985; Galal et al., 2008) were introduced in Spain from Israel in 1971 and the Assaf breed (i.e., 5/8 Awassi $\times$ 3/8 East Friesian) in 1977 (Ugarte et al., 2001). Both breeds are exploited in areas of the world with Mediterranean and subtropical climates. The Spanish Assaf breed was mainly produced by the backcross of Israeli Assaf individuals with the Castellana and Manchega local breeds, with the participation of Churra individuals being less clear (Legaz et al., 2008).

Currently, the Assaf and Awassi crossbreeds in Spain represent almost 900,000 sheep, mainly located in Castilla y León. The Assaf (approximately 90\%) are now used more than the Awassi crossbreeds (ca. 10\%) due to their high milk yields under intensive production systems. Moreover, few pure Awassi flocks currently exist in Spain, being the breed exploited under a different degree of backcrossing. Spanish Assaf was included as a "third country breed" in the Spanish catalog of livestock (Spanish Real Decreto 1682/97, modified by Orden APA/661/2006). The introduction of these foreign breeds has been accompanied by a dramatic reduction in the population of local breeds (i.e., Churra and Castellana) and by the intensification of the traditional production systems (Ugarte et al., 2001; Caja and de Rancourt, 2002; Mantecón et al., 2009).

Considering the scarce scientific references currently available on the performance and farming systems of the Assaf and Awassi crossbreeds farms in Spain, our research aimed to study the structural characteristics and performance of a group of Assaf and Awassi crossbreeds on commercial dairy sheep farms in northwestern Spain (Castilla y León), which were grouped for receiving technical support. A second aim was to establish an objective farm typology based on the structural, technical, and management variables.

\section{MATERIALS AND METHODS}

\section{Area of Study}

The area of study was located in the Autonomous Community of Castilla y León (provinces of León, Valladolid, and Zamora). Castilla y León is located in northwestern Spain and has an average altitude of 830 $\mathrm{m}$ above sea level (500 to $2,500 \mathrm{~m}$ ) and a low population density (27 inhabitants $/ \mathrm{km}^{2}$ ). Climate is Mediterranean under continental influence, with dry and hot summers and cool winters. Average rainfall ranges between 300 and $500 \mathrm{~mm}$, peaking in spring and autumn. Sheep farms are located on large planes devoted to crop production (mainly cereals, grain legumes, alfalfa, sugar beet, and vineyards). Dehydrated forage and agroindustrial byproducts are also a common fodder resource for livestock in the area.

\section{Data Collection}

The information was obtained by a survey carried out in 2006 by directly interviewing the owners of a selected sample of dairy sheep farms $(n=69)$ in the Autonomous Community of Castilla y León (Spain). The sample was chosen among 493 commercial farms of Assaf and Awassi crossbred dairy sheep receiving technical advice on feeding and economical management (GEO, Gestión Empresarial de Ovino, Castilla y León, Spain) during the last 5 yr. Sampled farms were elected, after eliminating the extreme values of the structural features, according to the availability and reliability of the managerial data and technical criteria (i.e., more than $10 \mathrm{yr}$ of experience and expecting to continue in the activity, representing the modern specialized dairy sheep farms under intensified production systems, and following the common management practices in the area). The farm data were collected by filling out the respective questionnaires jointly by the stakeholder and the authors.

Data collected corresponded to the average of the 2004 and 2005 economical and productive performances recorded in flock books, milk and lamb invoices, and farm accountancy. Milk yield and milk quality data (i.e., fat, protein, SCC, and bacterial count) from private or official milk recording services (i.e., monthly records from the Dairy Interprofessional Laboratory of Castilla y León), as well as from the monthly milk invoices issued by the dairy industries (i.e., raw milk quality payment system for bonus and penalties) were used. Lacking data were interpolated. All of these data were used for making decisions on the feeding and economical management technical support by the GEO advisors. Weighted means of bulk tank milk quality data were calculated for each farm during the study period.

The survey's methodology was similar to that of Dubeuf (1995), Milán et al. (2006), and Nahed et al. (2006). The questionnaire included both quantitative and qualitative information, belonging to the following groups: (1) farm location and land use; (2) flock size, sheep breeds, and species other than sheep; (3) familiar and hired workers employed; (4) animal feed management and organization, feed typology, and origin; (5) reproduction, breeding management, and replacement; (6) productive performances; (7) farm facilities and 
Table 1. Active structural indicators and their classes used in the multiple correspondence analysis of dairy sheep farms $(\mathrm{n}=69)$

\begin{tabular}{|c|c|c|}
\hline Item & Class & $\mathrm{n}$ \\
\hline \multicolumn{3}{|l|}{ Total surface, ha } \\
\hline Small & 0 & 17 \\
\hline Medium & 0.1 to 60 & 35 \\
\hline Large & $>60$ & 17 \\
\hline \multicolumn{3}{|l|}{ Cereals surface, ha } \\
\hline Small & 0 & 37 \\
\hline Medium & 0.1 to 19.9 & 13 \\
\hline Large & $\geq 20.0$ & 19 \\
\hline \multicolumn{3}{|l|}{ Forage surface, ha } \\
\hline Small & 0 & 25 \\
\hline Medium & 0.1 to 26.9 & 27 \\
\hline Large & $\geq 27.0$ & 17 \\
\hline \multicolumn{3}{|c|}{ Concentrate dependency, \% } \\
\hline Low & $<25$ & 2 \\
\hline Medium-low & 25 to $<50$ & 7 \\
\hline Medium-high & 50 to 75 & 8 \\
\hline High & $>75$ & 52 \\
\hline \multicolumn{3}{|l|}{ Forage dependency, $\%$} \\
\hline Low & $<25$ & 11 \\
\hline Medium-low & 25 to $<50$ & 11 \\
\hline Medium-high & 50 to 75 & 21 \\
\hline High & $>75$ & 26 \\
\hline \multicolumn{3}{|l|}{ Flock size, no ewes } \\
\hline Small & $<310$ & 17 \\
\hline Medium & 310 to 599 & 33 \\
\hline Large & $>600$ & 19 \\
\hline \multicolumn{3}{|l|}{ Flock size variation $^{1}$} \\
\hline Increased & - & 32 \\
\hline Decreased & - & 6 \\
\hline No variation & - & 31 \\
\hline \multicolumn{3}{|l|}{ Labor, $\mathrm{AWU}^{2}$} \\
\hline Small & $<1.5$ & 18 \\
\hline Medium & 1.5 to 1.9 & 34 \\
\hline Large & $\geq 2.0$ & 17 \\
\hline \multicolumn{3}{|l|}{ Stakeholder age, yr } \\
\hline Young & $<38$ & 19 \\
\hline Medium & 38 to 46 & 33 \\
\hline Old & $\geq 47$ & 17 \\
\hline \multicolumn{3}{|l|}{ Ewes/AWU } \\
\hline Small & $<201$ & 21 \\
\hline Medium & 201 to 264 & 28 \\
\hline Large & $>265$ & 20 \\
\hline \multicolumn{3}{|l|}{ Housing facilities } \\
\hline Old & - & 8 \\
\hline Reformed & - & 25 \\
\hline New & - & 36 \\
\hline \multicolumn{3}{|c|}{ Electronic identification } \\
\hline None & - & 50 \\
\hline All flock & - & 13 \\
\hline Replacement stock & - & 6 \\
\hline \multicolumn{3}{|c|}{ Stakeholder education level } \\
\hline Primary & - & 53 \\
\hline High school & - & 16 \\
\hline \multicolumn{3}{|c|}{ Average milk yield, L/ewe-yr } \\
\hline Low & $<266$ & 19 \\
\hline Medium & 266 to 362 & 33 \\
\hline High & $\geq 363$ & 17 \\
\hline \multicolumn{3}{|c|}{ Average lactation length, d } \\
\hline Short & $<180$ & 18 \\
\hline Medium & 180 to 223 & 33 \\
\hline Long & $>224$ & 18 \\
\hline Average lambing inte & & \\
\hline Small & $\leq 8.0$ & 22 \\
\hline Medium & 8.1 to 10.9 & 24 \\
\hline
\end{tabular}

Continued
Table 1 (Continued). Active structural indicators and their classes used in the multiple correspondence analysis of dairy sheep farms (n $=69$ )

\begin{tabular}{|c|c|c|}
\hline Item & Class & $\mathrm{n}$ \\
\hline Large & $\geq 11$ & 23 \\
\hline \multicolumn{3}{|l|}{ Drying-off system } \\
\hline Short & - & 14 \\
\hline Progressive & - & 45 \\
\hline Milking omission & - & 10 \\
\hline \multicolumn{3}{|l|}{ Average $\log _{10}$ SCC } \\
\hline Low & $<5.60$ & 22 \\
\hline Medium & 5.61 to 5.83 & 26 \\
\hline High & $\geq 5.84$ & 21 \\
\hline \multicolumn{3}{|c|}{ Ewe-lamb replacement criterion } \\
\hline Milk yield & - & 42 \\
\hline Others & - & 27 \\
\hline \multicolumn{3}{|c|}{ Reproductive system } \\
\hline Continuous & - & 9 \\
\hline \multicolumn{3}{|l|}{ Discontinuous } \\
\hline Free & - & 11 \\
\hline Grouped & - & 12 \\
\hline Synchronized & - & 37 \\
\hline \multicolumn{3}{|c|}{ Artificial insemination of ewes } \\
\hline Partially & - & 16 \\
\hline None & - & 53 \\
\hline \multicolumn{3}{|c|}{ Average age at first lambing, mo } \\
\hline Early & $<13.5$ & 17 \\
\hline Medium & 13.5 to 15 & 24 \\
\hline Late & $>15$ & 28 \\
\hline \multicolumn{3}{|l|}{ Ewes/ram } \\
\hline Small & $<33$ & 17 \\
\hline Medium & 33 to 60 & 34 \\
\hline Large & $>60$ & 18 \\
\hline \multicolumn{3}{|c|}{ Ewe replacement rate, $\%$} \\
\hline Low & $<20$ & 16 \\
\hline Medium & 20 to 29 & 35 \\
\hline High & $>29$ & 18 \\
\hline \multicolumn{3}{|l|}{ Weaning age, $\mathrm{d}$} \\
\hline Early & $<35$ & 39 \\
\hline Late & $>35$ & 30 \\
\hline \multicolumn{3}{|c|}{ Ewes per milking stall } \\
\hline Low & $<11.5$ & 17 \\
\hline Medium & 11.5 to 17 & 33 \\
\hline High & $>17$ & 19 \\
\hline
\end{tabular}

${ }^{1}$ During the 5 yr previous to the survey.

${ }^{2}$ Annual work unit.

machinery; (8) flock health care; and (9) miscellaneous, including critical points and concerns.

\section{Statistical Analyses}

Descriptive and specific statistics were calculated for both the total farms and the farms grouped by breed by using SPSS software (version15, SPSS Inc., Chicago, IL). The differences between breeds regarding the continuous variables (and later between groups obtained from the typology) were contrasted by a Student's $t$-test, for comparisons between 2 groups, or by a oneway ANOVA with the Student-Newman-Keuls mean comparison test, when the comparison was between more than 2 groups. Differences between qualitative 
Table 2. Structural characteristics of Assaf and Awassi crossbreed dairy sheep farms in northwestern Spain $(\mathrm{n}=69)$

\begin{tabular}{lcc}
\hline Item & Mean $\pm \mathrm{SE}$ & Interval \\
\hline Dairy specialization, $\%$ & 100 & - \\
Total surface, ha & $55.4 \pm 10.4$ & 0 to 480 \\
Ownership surface, $\%$ & $44.5 \pm 5.6$ & 0 to 100 \\
Surface, ha & $17.2 \pm 5.1$ & 0 to 300 \\
$\quad$ Cereals & $19.4 \pm 4.8$ & 0 to 300 \\
Forage & $14.5 \pm 5.8$ & 0 to 300 \\
Pastures & $493.1 \pm 29.1$ & 177 to 1,500 \\
Ewes, $\mathrm{n}$ & $2.1 \pm 0.11$ & 1 to 5 \\
Labor & $90.2 \pm 2.2$ & 20 to 100 \\
$\quad$ Total, AWU ${ }^{1}$ & $42.2 \pm 1.0$ & 26 to 63 \\
Familiar, $\%$ & 82.6 & - \\
Stakeholder age, yr & $147.0 \pm 8.2$ & 30 to 397 \\
Associated in cooperatives, $\%$ & & \\
Milk yield, $\mathrm{L} \times 10^{3} / \mathrm{yr}$ & &
\end{tabular}

${ }^{1}$ Annual work unit.

data were contrasted through a Pearson chi-square test of contingency tables. Pearson correlations among continuous variables were also calculated.

For farm classification, a multivariate analysis, based on quantitative and qualitative variables, was performed. Because a large proportion of the variables was qualitative, the multiple correspondence analysis (MCA), implemented in the SPAD 4.5 software (Coheris, Suresnes, France), was used. The MCA reduces the dimensions of contingency tables and gives a graphical representation of the information contained in these tables in a new space of independent factors where the similar categories of different variables appear closer. Quantitative variables were transformed into 3 classes, using the quantile position with respect to the mean. This provided the frequencies of observations that were within the quantiles: $<25 \%$, between 25 and $75 \%$, and $>75 \%$ of the mean value for a chosen variable. A stepwise procedure was carried out to eliminate the variables in which the sum of contributions to the formation of the first 4 factors obtained with the MCA was less than the averaged $12 \%$ (i.e., province, breed, lambing-mating interval, bacterial count, lambs per ewe, and milk fat and milk protein contents). The 26 active variables finally used in the MCA are shown in Table 1. The MCA allowed us to detect the factors that best characterized the farms and their uses in the subsequent analyses and avoided the need of standardizing the variables used.

A hierarchical cluster analysis was done with the first 4 factors showing the greatest variance, generated by the MCA. Cluster analysis allowed grouping the farms that were similar between them (minor within-group variance) and different to the others (greater variance between groups). Finally, mean structural and technical indicators which defined each group were calculated, and contingency tables with qualitative variables were built.

\section{RESULTS AND DISCUSSION}

\section{Structural Characteristics of Dairy Sheep Farms}

After stratifying by breed and province, the 69 questionnaires completed were allocated in 48 Assaf (69.6\%) and 21 Awassi crossbreed (30.4\%) farms. Sample partitioning by provinces in Castilla y León was: León (44.9\%), Valladolid (11.6\%), and Zamora (43.5\%).

Farm and Flock Size. All of the sheep farms in the considered sample had dairy specialization but largely variable flock size (177 to 1,500 ewes; Table 2), without sharing the farm with other livestock species (Table 2). Although Spanish data for dairy sheep farms is incomplete (INE, 2010), most dairy sheep farms are known as fully devoted to milk production. On the contrary, many French dairy sheep farms shared dairy sheep activity with other livestock activities, whereas in the specialized French dairy sheep area of Roquefort, a similar situation to the one in our study was reported (Morin et al., 2004).

The average flock size was 2.4 times greater (Table 2) than the average of sheep farms in Spain (203 ewes/ farm) and 1.5 times greater than in Castilla y León (326 ewes/farm) according to the Spanish National Statistics Institute (INE, 2010). Moreover, approximately one-half of the farms had increased their flock size in the previous 5 yr (Table 3). The average flock size was largely greater than the current European Union average flock size (63.4 ewes/farm; Eurostat, 2010) and greater than the averages of the US meat (67.8 ewes/ flock; NRC, 2008) and dairy sheep (145 ewes/flock; Thomas, 2004) industries. The average flock size reported in our study was also greater than the 302 ewes/ flock reported on average for the Roquefort dairy sheep industry in France (Morin et al., 2004).

The total farm surface, although varying largely (Table 2), was similar to that reported for specialized sheep farms in Spain (55.4 ha) but smaller than in 
Table 3. Dairy sheep farm partitioning ${ }^{1}$ for each qualitative variable class according to groups obtained in the cluster analysis: basic and infrastructural traits

\begin{tabular}{|c|c|c|c|c|c|c|}
\hline \multirow[b]{2}{*}{ Item } & \multirow[b]{2}{*}{ Overall } & \multicolumn{4}{|c|}{ Group $^{2}$} & \multirow[b]{2}{*}{$P$-value } \\
\hline & & $\begin{array}{c}\mathrm{I} \\
(\mathrm{LSAw})\end{array}$ & $\begin{array}{c}\text { II } \\
\text { (LFAs) }\end{array}$ & $\begin{array}{c}\text { III } \\
\text { (HYAs) }\end{array}$ & $\begin{array}{c}\text { IV } \\
(\mathrm{NLAs})\end{array}$ & \\
\hline Flock breed & - & - & - & - & - & 0.075 \\
\hline Awassi $^{3}$ & 30.4 & 62.5 & 38.1 & 17.2 & 27.3 & - \\
\hline Assaf & 69.6 & 37.5 & 61.9 & 82.8 & 72.7 & - \\
\hline Flock size variation ${ }^{4}$ & - & - & - & - & - & 0.008 \\
\hline Increased & 46.4 & 25.0 & 52.4 & 58.6 & 18.2 & - \\
\hline Decreased & 8.7 & 37.5 & 9.5 & 3.4 & 0 & - \\
\hline Registered in Breed Association & 24.6 & 0 & 14.3 & 48.3 & 0 & 0.001 \\
\hline No-land farms & 24.6 & 0 & 0 & 27.6 & 81.8 & 0.001 \\
\hline \multicolumn{7}{|l|}{ Fodder crops } \\
\hline Cereals & 46.4 & 87.5 & 47.6 & 51.7 & 0 & 0.002 \\
\hline Alfalfa & 43.5 & 75.0 & 81.0 & 24.1 & 0 & 0.001 \\
\hline Ryegrass & 14.5 & 25.0 & 19.0 & 13.8 & 0 & 0.401 \\
\hline Vetch & 26.1 & 62.5 & 33.3 & 20.7 & 0 & 0.016 \\
\hline Corn & 23.2 & 37.5 & 33.3 & 20.7 & 0 & 0.135 \\
\hline Vetch-oat & 26.1 & 50.0 & 28.6 & 27.6 & 0 & 0.096 \\
\hline \multicolumn{7}{|l|}{ Self-produced fodder } \\
\hline Consumed & 69.1 & 100 & 90.5 & 64.3 & 18.2 & 0.001 \\
\hline Commercialized & 25.0 & 62.5 & 42.9 & 10.7 & 0 & 0.001 \\
\hline High school or graduate education & 23.5 & 12.5 & 15.0 & 31.0 & 27.3 & 0.504 \\
\hline External managerial activity & 7.2 & 25.0 & 9.5 & 3.4 & 0 & 0.145 \\
\hline Housing facilities & - & - & - & - & - & 0.005 \\
\hline Old & 11.6 & 12.5 & 23.8 & 0 & 18.2 & - \\
\hline Reformed & 36.2 & 12.5 & 57.1 & 27.6 & 36.4 & - \\
\hline New & 52.2 & 75.0 & 19.0 & 72.4 & 45.5 & - \\
\hline Electronic identification & - & - & - & - & - & 0.001 \\
\hline None & 72.5 & 100 & 95.2 & 37.9 & 100 & - \\
\hline All flock & 18.8 & 0 & 0 & 44.8 & 0 & - \\
\hline Replacement stock & 8.7 & 0 & 4.8 & 17.2 & 0 & - \\
\hline \multicolumn{7}{|l|}{${ }^{1}$ Values are in percentages. } \\
\hline \multicolumn{7}{|c|}{$\begin{array}{l}{ }^{2} \text { LSAw = large-surface farms predominantly with Awassi crossbreed sheep; LFAs = large flocks predominant } \\
\text { with Assaf sheep; HYAs = high-yielding predominantly with Assaf sheep; NLAs = no-land farms predom } \\
\text { nantly with Assaf sheep. }\end{array}$} \\
\hline
\end{tabular}

Castilla y León (82.0 ha; INE, 2010) and in the dairy sheep farms of Roquefort (69.0 ha; Morin et al., 2004); $24.6 \%$ of farms in our sample were no-land farms (Table 3). Nevertheless, the average farm surface when no-land farms were excluded was 73.4 ha. Ewe per ha ratios, considering the total average farm surface, were greater in our study (8.9 ewes/ha) than those in Spain, in Castilla y León, and in Roquefort (3.5, 4.0, and 4.4 ewes/ flock, respectively). Most farms cultivated their own forage (i.e., alfalfa, vetch, and vetch-oat), but cereal crops and natural pastures were also frequent (Tables 2 and 3). A total of $69.1 \%$ of farms used feeds produced on their own land. A dramatic difference was observed with regard to the land devoted to forage production, when the percentage calculated from our values $(43.6 \%$; according to data in Table 2) was compared with that of Roquefort dairy sheep farms (79\%; Morin et al., 2004).

Stakeholders. About half of the farm surface was owned by the stakeholders (Table 2), the rest being rented to landowners, which was markedly lower than
Spain's average land ownership in the sheep-specialized farms (78.5\%; INE, 2010).

Most farm labor was performed by the family unit (Table 2) and stakeholders were young men and women (i.e., $70.6 \%$ younger than $45 \mathrm{yr}$ of age) in agreement with data reported in Assaf dairy sheep farms in Castilla y León (Mantecón et al., 2009) and in Roquefort dairy sheep farms (Morin et al., 2004). Both values markedly differ with data previously reported by Alonso et al. (2001) in dairy sheep farms using local breeds in Castilla y León, indicating that younger farmers chose the foreign high-yielding sheep breeds for their farms. Work power efficiency in the dairy sheep farms, estimated as ewes per annual work unit (AWU), was markedly greater in our study (234.8 ewes/AWU) than in Roquefort (131.3 ewes/AWU; Morin et al., 2004). Nevertheless, it should be emphasized than the Roquefort farmers devoted part of their time to forage production, whereas more than $67 \%$ of farms in our study bought more than half of the required forage (Table 4). 
Table 4. Dairy sheep farm partitioning ${ }^{1}$ for each qualitative variable class according to groups obtained in the cluster analysis: flock management traits

\begin{tabular}{|c|c|c|c|c|c|c|}
\hline \multirow[b]{2}{*}{ Item } & \multirow[b]{2}{*}{ Overall } & \multicolumn{4}{|c|}{ Group $^{2}$} & \multirow[b]{2}{*}{$P$-value } \\
\hline & & $\begin{array}{c}\mathrm{I} \\
(\mathrm{LSAw})\end{array}$ & $\begin{array}{c}\mathrm{II} \\
(\mathrm{LFAs})\end{array}$ & $\begin{array}{c}\text { III } \\
\text { (HYAs) }\end{array}$ & $\begin{array}{c}\text { IV } \\
\text { (NLAs) }\end{array}$ & \\
\hline Grazing & 50.7 & 62.5 & 71.4 & 37.9 & 36.4 & 0.077 \\
\hline TMR & 33.3 & 25.0 & 42.9 & 37.9 & 9.1 & 0.232 \\
\hline \multirow{2}{*}{$\begin{array}{l}\text { Forage dependency } \\
<25 \%\end{array}$} & - & - & - & - & - & 0.001 \\
\hline & 16.2 & 87.5 & 10.0 & 6.9 & 0 & - \\
\hline 25 to $50 \%$ & 16.2 & 12.5 & 25.0 & 17.2 & 0 & - \\
\hline$>50$ to $75 \%$ & 29.4 & 0 & 50.0 & 24.1 & 27.3 & - \\
\hline$>75 \%$ & 38.2 & 0 & 15.0 & 51.7 & 72.7 & - \\
\hline Concentrate dependency & - & - & - & - & - & 0.116 \\
\hline$<25 \%$ & 2.9 & 0 & 0 & 6.9 & 0 & - \\
\hline 25 to $50 \%$ & 10.1 & 25.0 & 9.5 & 10.3 & 0 & - \\
\hline$>50$ to $75 \%$ & 11.6 & 37.5 & 9.5 & 10.3 & 0 & - \\
\hline$>75 \%$ & 75.4 & 37.5 & 81.0 & 72.4 & 100 & - \\
\hline \multicolumn{7}{|l|}{ Ration ingredients } \\
\hline Hay & 68.1 & 100 & 81.0 & 55.2 & 54.5 & 0.037 \\
\hline Dehydrated forage & 69.6 & 50.0 & 76.2 & 75.9 & 54.5 & 0.308 \\
\hline Silage & 11.6 & 25.0 & 19.0 & 6.9 & 0 & 0.203 \\
\hline Fresh forage & 24.6 & 50.0 & 9.5 & 27.6 & 27.3 & 0.137 \\
\hline Lamb rearing & - & - & - & - & - & 0.001 \\
\hline Suckling & 62.3 & 50.0 & 90.5 & 37.9 & 81.8 & - \\
\hline Milk substitute & 37.7 & 50.0 & 9.5 & 62.1 & 18.2 & - \\
\hline Concentrate & 86.8 & 87.5 & 95.2 & 86.2 & 70.0 & 0.287 \\
\hline Reproductive system & - & - & - & - & - & 0.001 \\
\hline Continuous & 13.0 & 0 & 14.3 & 3.4 & 45.5 & - \\
\hline \multicolumn{7}{|l|}{ Discontinuous } \\
\hline Free & 15.9 & 62.5 & 23.8 & 3.4 & 0 & - \\
\hline Grouped & 17.4 & 37.5 & 4.8 & 27.6 & 0 & - \\
\hline Synchronized & 53.6 & 0 & 57.1 & 65.5 & 54.5 & - \\
\hline Artificial insemination & 23.2 & 0 & 9.5 & 44.8 & 9.1 & 0.004 \\
\hline \multicolumn{7}{|c|}{ Ewe-lamb replacement criterion } \\
\hline Milk recording & 60.9 & 0 & 52.4 & 96.6 & 27.3 & 0.001 \\
\hline Morphology & 55.1 & 100 & 52.4 & 34.5 & 81.8 & 0.002 \\
\hline \multicolumn{7}{|c|}{ Ram-lamb replacement criterion } \\
\hline Milk recording & 62.3 & 75.0 & 57.1 & 72.4 & 36.4 & 0.158 \\
\hline Morphology & 47.8 & 25.0 & 57.1 & 37.9 & 72.7 & 0.099 \\
\hline Practicing milk recording & 65.7 & 14.3 & 55.0 & 96.6 & 36.4 & 0.001 \\
\hline Drying-off system & - & - & - & - & - & 0.001 \\
\hline Short & 20.3 & 12.5 & 38.1 & 6.9 & 27.3 & - \\
\hline Progressive & 65.2 & 87.5 & 38.1 & 93.1 & 27.3 & - \\
\hline Milking omission & 14.5 & 0 & 23.8 & 0 & 45.5 & - \\
\hline \multicolumn{7}{|l|}{ Milking routine } \\
\hline Machine stripping & 82.6 & 100 & 85.7 & 82.8 & 63.6 & 0.205 \\
\hline Teat dipping & 81.2 & 75.0 & 81.0 & 86.2 & 72.7 & 0.755 \\
\hline Intermediate massage & 40.6 & 12.5 & 38.1 & 41.4 & 63.6 & 0.164 \\
\hline
\end{tabular}

${ }^{1}$ Values are in percentages.

${ }^{2} \mathrm{LSAw}=$ large-surface farms predominantly with Awassi crossbreed sheep; LFAs = large flocks predominantly with Assaf sheep; HYAs = high-yielding predominantly with Assaf sheep; and NLAs = no-land farms predominantly with Assaf sheep.

Most stakeholders were married (76.1\%; data not shown), with primary $(76.5 \%)$ or high school (23.5\%) education and, among those older than $45 \mathrm{yr}$, one-half had a descendant to continue the farm activity (Table 2 and 3). Main incomes of stakeholders came from the dairy sheep farm, although $18.8 \%$ of them also had other incomes from several managerial external activities (Table 3). Most stakeholders were associated in cooperatives, but fewer than one-fourth of them were registered in the association of Spanish Assaf breeders (Table 3).

Farm Infrastructures and Management Facilities. The studied dairy sheep farms were located near small or medium-sized towns (i.e., 95.7\% closer than $2 \mathrm{~km}$ ) and had good road access. They had modern basic facilities (electricity, 91.3\%; sanitized water network from the town, $72.5 \%$ ) and had new or renewed farmhouses (88.4\%), as shown in Table 3 . 
Table 5. Feeding allowances ${ }^{1}$ offered to Assaf and Awassi crossbreed ewes according to stage of lactation in dairy sheep farms in northwestern Spain $(\mathrm{n}=69)$

\begin{tabular}{lccc}
\hline Stage & $\begin{array}{c}\text { Concentrate, } \\
\mathrm{kg} / \mathrm{d}\end{array}$ & $\begin{array}{c}\text { Forage, } \\
\mathrm{kg} / \mathrm{d}\end{array}$ & $\begin{array}{c}\text { Concentrate, } \\
\%\end{array}$ \\
\hline Mating & $1.49 \pm 0.07$ & $1.18 \pm 0.06$ & $55.2 \pm 1.7$ \\
Late pregnancy & $0.94 \pm 0.03$ & $0.95 \pm 0.05$ & $50.8 \pm 1.7$ \\
Early lactation & $1.97 \pm 0.06$ & $1.31 \pm 0.06$ & $60.5 \pm 1.5$ \\
Midlactation & $1.74 \pm 0.05$ & $1.43 \pm 0.06$ & $55.6 \pm 1.5$ \\
Late lactation & $1.09 \pm 0.05$ & $1.25 \pm 0.07$ & $47.1 \pm 1.6$ \\
Drying-off & $0.45 \pm 0.03$ & $1.02 \pm 0.06$ & $32.2 \pm 1.9$ \\
\hline
\end{tabular}

${ }^{1}$ Values are mean $\pm \mathrm{SE}$.

All farms had new closed barns with structures made of reinforced concrete or iron with galvanized roofing for the permanent stabulation of the sheep in large pens. Pens were on the ground floor, straw bedded and able to be cleaned by a tractor. All farms used machine milking in modern milking parlors but very few farms had a working chute $(4.3 \%)$, dipping bath $(4.3 \%)$, or foot bath $(10.1 \%)$ for sheep.

All sheep wore visual tags and, at the date of the survey, $27.5 \%$ of farms had already implemented the compulsory electronic identification of sheep by rumen boluses according to Spanish legislation (Real Decreto 947/2005, amended by Real Decreto 1486/2009). Nevertheless, farmers did not have their own electronic readers, which were provided by the technical and veterinary services when necessary (e.g., milk recording, blood sampling).

\section{Feeding and Management Practices}

All farms used intensive production systems with indoor feeding, although $50.7 \%$ of flocks grazed occasionally for a few days in cultivated fields next to the barns (Table 4). On the contrary, $43 \%$ of farms in Roquefort had permanent grazing land for the dairy ewes (Morin et al., 2004). The grazing seasons were spring (i.e., on cultivated alfalfa and fallow lands), and summer and autumn (i.e., on barley and corn stubbles), according to the Mediterranean rain pattern.

Indoor feeding was mainly based on rationed forage and concentrate, fed separately $(66.7 \%)$, and the rest of the farms used TMR (33.3\%). A total of 67.6 and $87.0 \%$ of farms bought more than one half of the forage and concentrates needed, respectively (Table 4), indicating a high degree of external dependency and an insufficient amount of cultivable land for flock feeding. Most farms used hay or dehydrated forage $(69.6 \%)$, and to a lower extent, green forage $(24.6 \%)$ and silage $(11.6 \%)$. When available, self-produced cereals (i.e., barley, triticale, corn, and rye) were also used for the farm-made concentrate mixtures. The concentrate-to-forage ratio used varied according to the ewe's production stage requirements, ranging from 32.2 to $60.5 \%$ (Table 5). These values agreed with the local practice of using diets with high amounts of concentrate, as reported by Gómez-Cortés et al. (2008, 2009) for the Assaf breed, but were greater than the levels calculated for dairy sheep with the same level of milk yield according to Cannas (2002) and INRA (2007).

Eighty-seven percent of farms used planned breeding and grouped the mating of the ewes (Table 4).The rest of the farms maintained the rams with the ewes permanently, allowing free mating during the whole year. In all cases, the main breeding aim was to spread the lambing season over the year to extend milk supply. This situation is general in the Spanish market, in contrast to the French dairy sheep market where the milk industries only collect milk during a fixed annual campaign (i.e., November 15 to August 31 in the Roquefort area; Morin et al., 2004). With this in mind, almost one-half of farms synchronized ewe estrus with vaginal sponges and did ram mating during spring; AI was rarely used and only a quarter of farms did it for pure breed ewe lambs (Table 4). No melatonin implants were used at the time of the survey in the studied farms. Estrus synchronization and AI in the Roquefort dairy farms was markedly greater, reaching almost two-thirds of the flocks (Morin et al., 2004). As a result of the flock breeding pattern, most of our studied farms extended the lambing season over the year (winter to spring), offering the maximum milk amount during spring. The average lambing interval was $9.6 \pm 0.2$ mo. When only a single annual lambing was planned (12-mo lambing interval), mating was performed during June to have lambing during the end of the fall season and to sell the lambs at Christmas as milk-fed lambs (lechazo, approximately $10 \mathrm{~kg}$ of BW; Table 6 ).

The ewe-to-ram ratio was high but very variable as a consequence of the extended breeding period (Table 6). Rams usually came from the same flock, although $86 \%$ farms occasionally also bought rams from other flocks. The main selection criterion for choosing replacement ram- and ewe-lambs was mother milk yield, followed by the morphological traits of the actual replacement 
Table 6. Reproductive management traits and performance of Assaf and Awassi crossbreed dairy sheep farms in northwestern Spain $(\mathrm{n}=69)$

\begin{tabular}{|c|c|c|}
\hline Item & Mean $\pm \mathrm{SE}$ & Interval \\
\hline \multicolumn{3}{|l|}{ Reproduction } \\
\hline Age at first lambing, mo & $14.4 \pm 0.2$ & 12 to 18 \\
\hline Lambing interval, mo & $9.6 \pm 0.2$ & 7 to 12 \\
\hline Lambing-mating interval, mo & $4.5 \pm 0.2$ & 2 to 8 \\
\hline Ewes/ram & $52.0 \pm 3.5$ & 17.7 to 200.0 \\
\hline Replacement rate, $\%$ & $25.2 \pm 1.1$ & 7.7 to 43.6 \\
\hline Lactation length, d & $199 \pm 5$ & 120 to 300 \\
\hline \multicolumn{3}{|l|}{ Milk } \\
\hline Annual yield, L/ewe & $309.4 \pm 8.0$ & 169.5 to 450.0 \\
\hline Fat, ${ }^{1} \%$ & $6.5 \pm 0.1$ & 5.1 to 8.2 \\
\hline Protein, ${ }^{1} \%$ & $5.3 \pm 0.1$ & 3.6 to 6.5 \\
\hline $\mathrm{ECM}^{2} \mathrm{~L} /$ ewe & $281.0 \pm 7.1$ & 109.4 to 414.2 \\
\hline $\mathrm{SCC}, 1 \times 10^{3}$ cells $/ \mathrm{mL}$ & $579.4 \pm 33.0$ & 200 to 2,000 \\
\hline $\log _{10} \mathrm{SCC}^{1}$ & $5.73 \pm 0.02$ & 5.30 to 6.30 \\
\hline Bacterial count, ${ }^{1} \times 10^{3} \mathrm{cfu} / \mathrm{mL}$ & $96.7 \pm 7.9$ & 30 to 450 \\
\hline Bacterial count, ${ }^{1} \log _{10} \mathrm{cfu} / \mathrm{mL}$ & $4.93 \pm 0.02$ & 4.48 to 5.65 \\
\hline \multicolumn{3}{|l|}{ Annual lamb crop } \\
\hline Per ewe & $1.35 \pm 0.04$ & 0.60 to 2.00 \\
\hline Weight, $\mathrm{kg}$ of BW & $10.4 \pm 0.1$ & 9.5 to 12.0 \\
\hline Age at harvesting, $\mathrm{d}$ & $23.2 \pm 0.4$ & 18 to 30 \\
\hline
\end{tabular}

lambs (Table 4). Estimated breeding values for Spanish Awassi and Assaf rams and ewes are not yet available, as indicated in the last report of the working group on milk recording of sheep of the International Committee for Animal Recording (ICAR; Astruc et al., 2009). Data in Table 6 show an early age at first lambing as a result of a precocious breeding of the ewe-lambs (7 to 13 mo of age), as previously reported by Pollott and Gootwine (2004) in Assaf. Nevertheless, a negative effect on milk yield $(-3.7 \mathrm{~L} / \mathrm{mo})$ was observed by Pollott and Gootwine (2004) in Assaf ewes mated at early ages. Moreover, a high replacement rate was observed in the flocks in our study, resulting in a short ewe lifespan (approximately $4.0 \mathrm{yr}$ ). The lifespan value in our study was lower than that in Churra dairy ewes submitted to an annual lambing system (5.7 yr) or to an accelerated lambing system (6.5 yr) in Castilla y León, as reported by El-Saied et al. (2006).

Although most farms suckled the lambs from their mothers (Table 4), artificial lamb rearing with milk powder substitutes was done in approximately onethird of the farms (automatic, 80.8\%; manual, 19.2\%). For artificial rearing, lambs were separated from the ewes as soon as possible after birth and colostrums were machine milked and individually administered to the lamb by bottle feeding. Lambs harvested as lechazo were weaned earlier $(23.2 \pm 0.4 \mathrm{~d})$ than were lambs intended for replacement $(36.6 \pm 1.0 \mathrm{~d})$.

Sheep disease prevention programs were generalized in the studied farms, and most sheep were vaccinated against enterotoxemia (95.7\%), contagious agalactia
(78.3\%), and pasteurellosis (59.4\%); vaccination against pulmonary adenomatosis $(28.6 \%)$, chlamydial abortion $(23.2 \%)$, gangrenous mastitis (18.8\%), and brucellosis $(5.8 \%)$ were less frequently used; veterinary services also blood sampled yearly all the flocks for brucellosis and Maedi-visna virus control, according to mandatory regulations in Castilla y León. At the time of the survey, official programs for resistance to scrapie (prion genotyping) and blue-tongue (serotype 4 vaccination) were being implemented.

\section{Production Performances}

Sheep performances in the studied farms are shown in Table 6. With regard to milk recording, $65.7 \%$ of farms (Table 4) performed AT4 official milk recording of ICAR guidelines. On average, lactation length was approximately $6.5 \mathrm{mo}$, including the suckling period when practiced. Nevertheless, a large range of variation was observed between farms (4 to $10 \mathrm{mo}$ ), depending on milk yield and the management system used. As can be calculated from Table 6, daily milk sold per ewe in the studied farms was $0.85 \pm 0.02 \mathrm{~L} / \mathrm{d}$, on average, varying largely ( 0.33 to $1.23 \mathrm{~L} / \mathrm{d}$ ) between farms and according to flock yield and management conditions.

Milk yield by lactation averaged $252.8 \pm 8.8 \mathrm{~L}$ /ewe in our study, which was similar to the range of values reported by Gootwine and Goot (1996) for Awassi and their crosses with East Friesian (185 to $248 \mathrm{~L} /$ ewe), but lower than the values reported by Gootwine and Pollott (2000) in Awassi (506 L/ewe), and Pollott and Gootwine 
(2004) in Assaf (334 L/ewe). Milk yield values reported in Castilla y León for the Churra local breed are $138 \mathrm{~L} /$ ewe in $120 \mathrm{~d}$ (El-Saied et al., 2005). Moreover, our Assaf and Awassi crossbreeds milk yield data were greater than those reported for local breeds in Spain (89 to 165 L/ewe), Italy (203 L/ewe), and France (134 to $177 \mathrm{~L} /$ ewe), with the exception of the French Lacaune (290 L/ ewe), as reported in the ICAR's working group on milk recording of sheep (Astruc et al., 2009). Annual dairy sheep milk yield in the United States varies according to the geographical region, being on average $178 \mathrm{~L} /$ ewe (East, 212 L/ewe; Midwest, 140 L/ewe; Thomas, 2004; NRC, 2008).

With regard to milk quality, the average milk composition obtained in our study (Table 6) fell into the ranges of other Mediterranean dairy sheep breeds in fat (5.9 to 9.0\%; Boyazoglu and Morand-Fehr, 2001; Sanna et al., 2001; Carta et al., 2009) and protein contents (4.8 to 6.6\%; Othmane et al., 2002; Legarra and Ugarte, 2005). Compared with local breeds in Castilla y León, milk composition values in our study were lower than those reported in the Castellana breed (milk fat, $7.4 \%$; milk protein, 6.5\%; Alonso et al., 2001) and in the range of those in Churra for milk fat (6.5 to 6.8\%), but lower in milk protein (5.7 to $6.3 \%$ ) as reported by Gonzalo et al. (1994) and Fuertes et al. (1998). Nevertheless, obtained values of milk components were greater than those reported on average in the US (milk fat, $6.2 \%$; milk protein, 4.9\%; Thomas, 2004). Milk composition values for Assaf and Awassi crossbreed ewes in our study were greater than the control values (milk fat, 4.5 to $6.2 \%$; milk protein, 4.6 to $5.2 \%$ ) reported in several recent experiments done with Assaf ewes by Gómez-Cortés et al. (2008, 2009) and Toral et al. (2010). It should be stressed that the above-indicated experiments done with Assaf ewes used diets with extremely high concentrate-to-forage ratios (i.e., 80:20) and the low-milk fat syndrome was observed (Gómez-Cortés et al., 2009). Milk composition values were closer to those observed in our study when the ewes were fed with a diet with lower concentrate-to-forage ratio (i.e., 50:50) as shown by Toral et al. (2010). The protein-to-fat ratio in milk ranged from $0.82 \pm 0.01$ in our study, to 0.85 to 0.95 for the above-indicated references (Gómez-Cortés et al., 2008; Toral et al., 2010), reaching 1.07 in Gómez-Cortés et al. (2009). Milk protein-to-fat ratio modifies cheese yield and features according to Guinee et al. (2007) and it is generally accepted that the ratio should not be greater than 0.9 for good cheese quality.

Mean milk $\log _{10}$ SCC in the farms of our study (Table 6 ) was similar to the $\log _{10}$ SCC values reported by Gonzalo et al. (2010; 5.8) for the machine-milked flocks of the Assaf breed treated at dry-off with antibiotics and included in the Consortium for Ovine Promotion
Table 7. Milking machine and milking routine in Assaf and Awassi crossbreed dairy sheep farms in northwestern Spain $(\mathrm{n}=69)$

\begin{tabular}{lc}
\hline Item & Farms, $\%$ \\
\hline Machine milking & 100 \\
Parlor design & \\
Single & 20.3 \\
Double & 78.3 \\
Carousel & 1.4 \\
Milk pipeline & \\
High & 33.3 \\
Medium & 5.8 \\
Low & 60.9 \\
Pulsator & \\
Pneumatic & 11.6 \\
Electronic & 88.4 \\
Milking routine & \\
Feeding included & 84.1 \\
Udder washing & 0 \\
Intermediate massage & 40.6 \\
Machine stripping & 82.6 \\
Hand stripping & 0 \\
Teat dipping & 81.2 \\
\hline
\end{tabular}

of Castilla y León. This dry-off practice was also used by $87.0 \%$ of the farms in our study. Moreover, our SCC values were lower than those reported for Castellana local breed farms in Castilla y León (Alonso et al., 2001), most of them using hand milking. $\log _{10}$ SCC values in our study were weakly correlated with ewes per milking stall $(\mathrm{r}=0.24 ; P<0.05)$, lambing to mating interval $(\mathrm{r}=-0.24 ; P<0.05)$, lactation length $(\mathrm{r}=-0.41$; $P<0.001)$, and milk yield $(\mathrm{r}=-0.53 ; P<0.001)$. Although there is not a European Union regulation on SCC for ewe's milk, values $\leq 1,000 \times 10^{3}$ cells $/ \mathrm{mL}$, as observed in $95.6 \%$ of the farms in our study, are widely considered acceptable for producing sheep dairy products (Riggio et al., 2009). Moreover, $42.6 \%$ of the farms showed SCC $<500 \times 10^{3}$ cells $/ \mathrm{mL}$, which is the agreed threshold for subclinical IMI in sheep (Berthelot et al., 2006). High SCC in dairy sheep is also associated with losses in milk production (Raynal-Ljutovac et al., 2007), decreased milk lactose concentration (RaynalLjutovac et al., 2007), increased hazard of ewes of being culled (Riggio et al., 2009), and increased antibiotic residues in milk (Gonzalo et al., 2010). Additionally to SCC, bacterial count values in the milk of the studied farms (Table 6) were in all cases far from the thresholds stated in European legislation (Directive 94/71/EEC) for dairy products made of thermically treated milk $(<$ $\left.1,500 \times 10^{3} \mathrm{cfu} / \mathrm{mL}\right)$ or raw milk $\left(<500 \times 10^{3} \mathrm{cfu} /\right.$ $\mathrm{mL})$. Reported values of bacterial count $\left(\log _{10} \mathrm{cfu} / \mathrm{mL}\right)$ in ewe milk in Castilla y León are in the range of 4.9 to 5.3 (Gonzalo et al., 2006; 2010).

All of the farms in our study sell the collected ewe milk to dairy industries to produce sheep cheeses according to traditional procedures. No on-farm milk transformation was observed in the studied farm sample. A similar 
Table 8. Effects of milking routine on milk performance of Assaf and Awassi crossbreed dairy sheep farms in northwestern Spain (n = 69)

\begin{tabular}{|c|c|c|c|c|c|c|}
\hline Item & \multicolumn{2}{|c|}{ Intermediate massage } & \multicolumn{2}{|c|}{ Machine stripping } & \multicolumn{2}{|c|}{ Teat dipping } \\
\hline Farms, n & 28 & 41 & 57 & 12 & 56 & 13 \\
\hline Lactation length, d & $203^{\mathrm{a}}$ & $196^{\mathrm{b}}$ & $201^{\mathrm{x}}$ & $192^{\mathrm{y}}$ & 201 & 192 \\
\hline Ewes/AWU ${ }^{1}$ & 245.6 & 231.9 & 237.2 & 238.5 & 231.2 & 264.5 \\
\hline Milk yield, L/ewe and yr & 322.6 & 300.3 & 309.9 & 306.7 & 320.1 & 263.2 \\
\hline Bacterial count,${ }^{2} \log _{10} \mathrm{cfu} / \mathrm{mL}$ & 4.89 & 4.97 & $4.96^{\mathrm{x}}$ & $4.82^{\mathrm{y}}$ & 4.95 & 4.88 \\
\hline
\end{tabular}

${ }^{\mathrm{a}, \mathrm{b}}$ Pairs of means within a row with different superscripts differ $(P<0.05)$. The SE values for lactation length and $\log _{10} \mathrm{SCC}$ were in the range of 6 to 7 and 0.03 to 0.04 , respectively.

${ }^{x, y}$ Pairs of means within a row with different superscripts tended to differ $(P<0.10)$. The SE values for lactation length and bacterial count were in the range of 6 to 7 and 0.02 to 0.08 , respectively.

${ }^{1}$ Annual work unit.

${ }^{2}$ Values are arithmetic means of weighted means for each farm.

situation was reported for the Roquefort area where only $2 \%$ of farms process their own milk into dairy products (Morin et al., 2004). On the contrary, $17 \%$ of dairy sheep farms in France (Morin et al., 2004) and $50 \%$ in the United States and Canada (Thomas, 2004) process the ewe's milk on the farm.

Lamb harvesting weight and age were quite similar between farms (Table 6), the harvested lambs being slaughtered as lechazo, which is a typical and highly appreciated traditional product of Castilla y León.

\section{Milking}

Machine milking was performed in all farms in our study, whereas only $20 \%$ of local breed farms (i.e., Castellana breed) used machine milking according to Alonso et al. (2001) in the same area 10 yr earlier. Most used a milking parlor design with double-sided parallel stalls (i.e., 24 to 78 stalls) with low milk pipeline, the same number of milking units, and electronic pulsators (Table 7); the remaining farms used single-sided parallel stalls (i.e., 12 to 24 stalls). Only 1 farm had a carousel milking parlor (24 rotary stalls for a flock of 507 ewes). On average, the milking parlor utilization rate was $15.4 \pm 0.8$ ewes/stall, ranging from 4.6 to 41.7 ewes/stall. All farms had a separate milking room next to the milking parlor with at least one refrigerated milk tank.

With regard to milking routine, distribution of concentrate at milking was common, as well as machine stripping and teat postdipping (Table 7). Previous stimulation by udder washing, as well as final hand stripping was not practiced (Table 7).

Milking routine variation effects on milk performance are shown in Table 8. Intermediate massage, which was used in Castilla y León to reduce residual milk when machine milking was introduced (Gonzalo and Ojeda, 1983), was still performed in more than one-third of the farms. The reason for maintaining the intermediate massage was to alleviate the milkability defects that were a consequence of the baggy udders frequently observed in the Assaf and Awassi crossbreed ewes (Gootwine et al., 1980). Nevertheless, intermediate massage slightly increased lactation length $(7 \mathrm{~d} ; P$ $=0.014)$ and decreased SCC $\left(-31.1 \times 10^{3}\right.$ cells $/ \mathrm{mL} ; P$ $=0.033$ ), as shown in our study (Table 8 ). The lack of effects of the intermediate massage on milk yield and milk composition also observed in our results agreed with those previously reported by Purroy et al. (1983) in Churra ewes.

Machine stripping, done at the end of machine milking, tended to increase lactation length $(P=0.063)$ and bacterial counts $(P=0.070)$, resulting in $9 \mathrm{~d}$ and 7.15 $\times 10^{3} \mathrm{cfu} / \mathrm{mL}$ more (Table 8$)$. No effects of machine stripping on milk yield and milk composition were observed in our study, as reported by Knight and Gosling (1995) in Dorset dairy sheep.

Teat dipping, done immediately after finalizing machine milking in $81.2 \%$ of farms (Table 8), did not improve SCC and bacterial counts in milk $(P>0.05$; Table 8). Despite teat dipping being a recommendable practice to maintain udder health, no effect of teat dipping on new IMI was found by Klinglmair et al. (2005) and Østerås et al. (2008) in dairy sheep and dairy cattle, respectively, in agreement with our results.

\section{Comparison of Assaf and Awassi Crossbreed Dairy Flocks}

No differences on productive traits were observed between farms in which the flock was mainly constituted by Assaf and Awassi crossbreed ewes $(P>0.05)$. Only 
Table 9. Structural characteristics and performance for each group of dairy sheep farms obtained in the cluster analysis $(\mathrm{n}=69)$

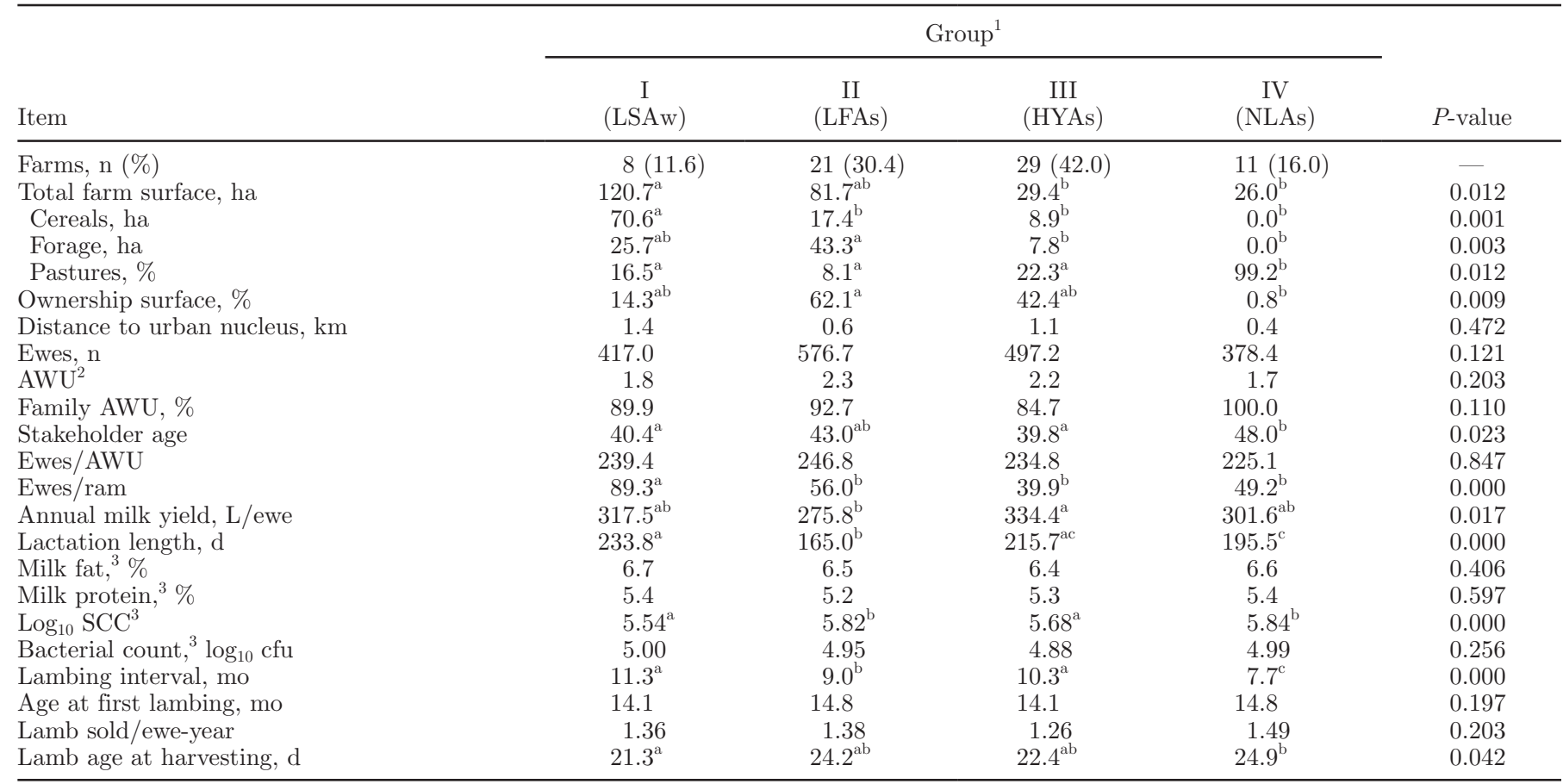

${ }^{\mathrm{a}-\mathrm{c}}$ Means within a row with different superscripts differ $(P<0.05)$.

${ }^{1} \mathrm{LSAw}=$ large-surface farms predominantly with Awassi crossbreed sheep; LFAs = large flocks predominantly with Assaf sheep; HYAs = high yielding predominantly with Assaf sheep; NLAs = no-land farms predominantly with Assaf sheep.

${ }^{2}$ Annual work unit.

${ }^{3}$ Values are arithmetic means of weighted means for each farm.

a few structural indicators showed signals that Awassi crossbreed were less intensive than Assaf farms (data not shown). This was the case with distance to urban nucleus and total farm surface, which were greater $(P$ $=0.002)$ or tended to be greater $(P=0.069)$, and with the amount of forage bought $(P=0.087)$, which tended to be lower, in the Awassi crossbreed than in the Assaf farms. The small differences found between Assaf and Awassi crossbreed flocks may be a consequence of the uncertain degree of crossbreeding observed in practice. So, farmers with morphologically predominating redheaded and fat-tailed ewes considered them Awassi, whereas the white-headed and thin and long-tailed ewes are considered as Assaf. Moreover, Awassi crossbreed flocks showed greater variability than Assaf flocks for most variables under study. These results agreed with the farm typologies detailed below.

\section{Dairy Sheep Farms Typology}

The first 4 factors showing the greatest variance in the MCA (totaling $28.2 \%$ of inertia) were used in the hierarchical cluster analysis to segment the farm sample into different types. Main variables (contributing more than $5 \%$ to each factor) were: factor 1 (inertia, $8.4 \%$ ), cereal surface, stakeholder age, lambing interval, ewe-toram ratio, age at first lambing, artificial insemination, ewe-lamb replacement criterion, drying-off system, and electronic identification; factor 2 (inertia, $7.7 \%$ ), total surface, cereal surface, forage dependency, concentrate dependency, reproductive system, ewe-to-ram ratio, and ewe-lamb replacement criterion; factor 3 (inertia, $6.4 \%$ ), total surface, forage surface, forage dependency, flock size, milk yield, lactation length, ewes per milking stall, and milk SCC; and, factor 4 (inertia, 5.7\%), forage surface, forage dependency, cereal surface, labor, milk yield, drying-off system, ewe-to-ram ratio, and electronic identification.

As a result, 4 groups, showing the lower intratype variance and the greater intertype variance, were obtained. Mean values of main qualitative variables (e.g., farm characteristics, available facilities, and management) for each typology group are shown in Tables 3 and 4 . Moreover, structural features (e.g., surface, flock size and labor) and performance traits (e.g., milk yield and milk quality) of each farm type are shown in Table 9.

The main common characteristics of all of the farms, not allowing discrimination between groups $(P>0.05)$, were: level of studies of the farmers and percentage of external activities done (Table 3); occasional grazing, 
use of forage ingredients and TMR, concentrate dependency, use of concentrate for lamb feeding, ram-lambs replacement criteria, and milking routine (Table 4); and labor productivity (e.g., AWU and ewes/AWU) and milk quality (Table 9). Flock size only tended to differ between groups $(P=0.12)$. These traits showed the great uniformity between farms and the relatively high degree of intensification for all the farms studied in the sample.

On the other hand, the main traits allowing discrimination between groups $(P<0.05)$, were: total surface and use of the land (i.e., cereal, forage or grazing; Table 9), external feeding dependence (Table 4), and milk yield, lactation length, and management practices (e.g., reproductive system and lambing interval), among others (Tables 4 and 9). According to these traits, 4 groups of sheep dairy farms were defined.

Group I: Large-Surface Farms Predominantly with Awassi Sheep. This group corresponded to 8 dairy sheep farms (11.6\%) having large surfaces $(>100$ ha) oriented to cereal production (59\%) and with a high degree of self-consumed commodities. The area devoted to forage production was also important $(21 \%)$, alfalfa and vetch being the most used cultures. In all cases, $>50 \%$ forage required for sheep feeding came from the same farm. Moreover, Awassi crossbreed flocks were the majority $(>60 \%)$ in the farms of the large-surface farms predominantly with Awassi sheep (LSAw) group. Flock size was intermediate (417 ewes/farm) and approximately one-third of farmers had reduced their flock in the previous 5 yr. In this LSAw group, farmers had a high level pluriactivity; more than $60 \%$ of the farms also sold nonsheep products. Ewe milk yield was intermediate ( $318 \mathrm{~L} / \mathrm{ewe})$, when compared with that of the other groups, but showed the longest lactation length $(P<0.05$; Table 9$)$. Regarding milking routine, although no differences between groups were detected, all LSAw farms practiced machine stripping, whereas intermediate massage was infrequent. Despite this, no differences in milk quality were observed, as indicated above. Typical reproductive management of the flock in the LSAw farms was discontinuous mating, with no hormonal treatments or AI. Number of ewes per ram was markedly greater in this group than in the others (Table $9 ; P<0.05$ ), which may be a consequence of a greater sexual activity throughout the year of the Awassi breed when compared with that of the Assaf (Amir and Gacitua, 1987; Galal et al., 2008). This difference was not appreciated in the Awassi and Assaf direct comparison $(P>0.05)$. Although replacement of ewe-lambs was done based on morphological criteria, ram-lambs selection was based on the milk-recording data of the mothers. Nevertheless, few farms practiced milk recording (14.3\%). Electronic identification was not used in any of the LSAw farms at the time of the survey.

Group II: Large Flocks Predominantly with Assaf Sheep. Twenty-one farms $(30.4 \%)$ integrated the large flocks predominantly with Assaf sheep (LFAs) group, which was characterized by large flocks (578 ewes/farm), intermediate farm surface ( 82 ha; ownership, $62 \%$ ), oriented to forage production (53\%), and alfalfa being the most used culture (Table 3). The Assaf flocks predominated in the LFAs group. Although most flocks in this group were fed with commodities produced in the farm, the level of external dependence for feeding was intermediate, with 91 and $65 \%$ of farms needing to buy more than a half of the concentrate and forage required, respectively. More than $40 \%$ of farmers of the LFAs group also sold nonsheep products (Table 9). This group showed the shortest lactation length $(P<0.05)$ and the lowest milk yield $(276 \mathrm{~L} /$ ewe) with an intermediate SCC value (Table 9). This lower productivity may be related to the frequent use of natural suckling (Table 4). Predominant reproductive management in the LFAs group was discontinuous mating with hormonal treatments, but AI was scarce. Both ewe- and ram-lambs selection was based on the milk-recording data of their mothers, as well as on morphological criteria. Approximately half of the farms $(55 \%)$ practiced milk recording. At the time of the survey, $<5 \%$ of farms used the electronic identification for replacement stock.

Group III: High-Yielding Predominantly with Assaf Sheep. The group included 29 farms (42.0\%) with flocks of intermediate size (497 ewes/farm) but the highest milk yield (334 L/ewe) and a long lactation (216 DIM). In this high-yielding predominantly with Assaf sheep (HYAs) group, Assaf flocks registered in the breed association were the majority (Table 3). Moreover, flock size had grown in the previous $5 \mathrm{yr}$. This group included the youngest farmers, equipped with new or renovated farmhouses and using the greatest percentage of unfamiliar work power $(P=0.11$; Table 9). External feed dependence was high, with 83 and $76 \%$ of farmers buying more than $50 \%$ of the concentrates and forage required, respectively. Typical reproductive flock management of HYAs farms was discontinuous mating with hormonal treatments; AI was done in approximately half of the flock of these farms. Almost all farms in the HYAs group performed milk recording, which was used as the main selection criteria for the replacement of ewe- and ram-lambs. Moreover, sheep electronic identification was widely implemented ( $>60 \%$ farms) at the time of the survey.

Group IV: No-Land Farms Predominantly with Assaf Sheep. Eleven farms (16.0\%) were included in this group, which was characterized by no-land farms 
$(82 \%)$ and being highly dependent on external feed. The rest of the farms (18\%) only had grazing land. Assaf flocks also were the majority in this no-land farms predominantly with Assaf sheep (NLAs) group. Flock size was the lowest (378 ewes/farm; $P=0.12$ ) of the groups and has steadied over the last $5 \mathrm{yr}$. All of the NLAs farms needed to buy more than $50 \%$ of the concentrates and forage required for sheep feeding. Farmers of this group were, on average, slightly older (48 yr) than farmers of other groups and used $100 \%$ family labor. The NLAs farms showed intermediate milk yield (302 L/ewe) and lactation length (196 DIM), and made a massive use of natural suckling (Table 4), as observed in group II-LFAs. The milking routine of NLAs farms included machine stripping and teat dipping with a similar frequency to that of the other groups; nevertheless, we observed a higher frequency of intermediate massage in these farms. With respect to reproductive management of the flock, continuous mating was done in almost half of the NLAs farms, the rest being discontinuous mating with hormonal treatment but with very few AI. On the other hand, this group had the lowest lambing interval (Table 9). The NLAs farms used morphology as the main criteria for both ewe- and ram-lambs selection. As in group I-LSAw, electronic identification was not used in any of the LSAw farms at the time of the survey.

Finally, a global comparison of the groups' features showed that dairy sheep farms included in group IIIHYAs were the most numerous and characterized by intermediate flock size with higher milk yield and more intensive production system than the other farms in the study. These farms used the available resources adequately, as well as modern technology and efficient management practices. Group II-LFAs, which was the second group in farm number, corresponded to large flocks with a low milk yield and, despite their intermediate availability of cultivable land, they showed a high external feeding dependency. Farms included in group IV-NLAs had no land and small-sized flocks, being characterized by their short lambing interval (a consequence of continuous mating), intermediate milk yield, and more traditional management practices. Group I-LSAw, in which more Awassi crossbreed flocks were found, was the least numerous on farms. It was characterized by large farm surfaces devoted to cereal and forage production and by having the greatest nondairy activity. Nevertheless, flock size and milk yield were intermediate in this group.

\section{CONCLUSIONS}

The dairy sheep farm sample studied allowed us to understand the main features of the new productive option adopted in Castilla y León (Spain) for the development of modern dairy sheep farms linked to the local cheese industry. The farms abandoned the traditional practices and local breeds, and adopted improved foreign breeds (Awassi and Assaf) exploited under intensive production systems. Moreover, the farms were based on familiar units, as are traditional farms, but proved to be highly dependent on external feeding resources and more vulnerable to market changes. Despite their apparent homogeneity, we detected 4 farm types with marked structural, productive, and managerial traits differences, depending on the availability of resources and the strategies followed. These differences will make dairy sheep farmers confront future uncertainties with different expectations of success.

\section{ACKNOWLEDGMENTS}

This work is part of a research project (Plan Nacional I+D+i; Project AGL-2006-07673) funded by the MCINN (Ministerio de Ciencia e Innovación, Madrid, Spain). The authors are grateful to the farmers of the Group GEO (Gestión Empresarial de Ovino) from Castilla y León (Spain) for taking part in this study, and to Nic Aldam (Barcelona, Spain) for the English revision of the manuscript.

\section{REFERENCES}

Alonso Alonso, E., M. C. González Rodríguez, and P. A. Redondo Cardeña. 2001. Análisis del manejo de la oveja de raza Castellana. Arch. Zootec. 50:375-378.

Amir, D., and H. Gacitua. 1987. Sexual activity of Assaf ewes after October and February lambings. Theriogenology 27:377-382.

Astruc, J. M., F. Barillet, A. Carta, M. Fioretti, E. Gootwine, D. Kompan, F. J. Romberg, and E. Ugarte. 2009. Report of the ICAR working group on milk recording of Sheep. Pages 275-281 in Proc. of the 36th Biennial Session of the International Committee for Animal Recording (ICAR), Niagara Falls, NY. ICAR technical series no. 13. Identification, breeding, production, health and recording of farm animals. J.D. Sattler, ed. ICAR, Rome, Italy.

Berthelot, X., G. Lagriffoul, D. Concordet, F. Barillet, and D. Bergonier. 2006. Physiological and pathological thresholds of somatic cell counts in ewe milk. Small Rumin. Res. 62:27-31.

Boyazoglu, J., and P. Morand-Fehr. 2001. Mediterranean dairy sheep and goat products and their quality. A critical review. Small Rumin. Res. 40:1-11.

Caja, G., and M. de Rancourt. 2002. Situation actuelle et perspectives de la production des ovins laitiers en Espagne. Opt. Médit.. Sér. B: Etudes et Recherches 39:57-66.

Cannas, A. 2002. Feeding of lactating ewes. Pages 123-166 in Dairy Sheep Feeding and Nutrition. G. Pulina, ed. Avenue Media, Bologna, Italy.

Carta, A., S. Casu, and S. Salaris. 2009. Current state of genetic improvement in dairy sheep. J. Dairy Sci. 92:5814-5833.

Dubeuf, B. 1995. Relations entre les caractéristiques des laits de troupeaux, les pratiques d'élevage et les systèmes d'exploitation dans la zone de production du Beaufort. INRA Prod. Anim. 8:105-116.

El-Saied, U. M., L. F. de la Fuente, J. A. Carriedo, and F. San Primitivo. 2005. Genetic and phenotypic parameter estimates of total and partial lifetime traits for dairy ewes. J. Dairy Sci. 88:3265-3272.

El-Saied, U. M., L. F. de la Fuente, and F. San Primitivo. 2006. Lifetime traits comparison between annual and accelerated lambing systems for dairy ewes. Livest. Sci. 101:180-190. 
Epstein, H. 1982. Awassi sheep. World Anim. Rev. 44:11-27.

Epstein, H. 1985. The Awassi sheep with special reference to the improved dairy type. FAO Animal Production and Health. Paper No. 57. Rome, Italy.

Eurostat. 2010. Official European Union Statistics. Accessed Apr. 3, 2010. http://epp.eurostat.ec.europa.eu/portal/page/portal/ agriculture/data

Fuertes, J. A., C. Gonzalo, J. A. Carriedo, and F. San Primitivo. 1998. Parameters of test day milk yield and milk components for dairy ewes. J. Dairy Sci. 81:1300-1307.

Galal, S., O. Gürsoy, and I. Shaat. 2008. Awassi sheep as a genetic resource and efforts for their genetic improvement-A review. Small Rumin. Res. 79:99-108.

Gómez-Cortés, P., P. Frutos, A. R. Mantecón, M. Juárez, M. A. de la Fuente, and G. Hervás. 2008. Milk production, conjugated linoleic acid content, and in vitro ruminal fermentation in response to high levels of soybean oil in dairy ewe diet. J. Dairy Sci. 91:15601569.

Gómez-Cortés, P., P. Frutos, A. R. Mantecón, M. Juárez, M. A. de la Fuente, and G. Hervás. 2009. Effect of supplementation of grazing dairy ewes with a cereal concentrate on animal performance and milk acid profile. J. Dairy Sci. 92:3964-3972.

Gonzalo, C., J. A. Carriedo, J. A. Baro, and F. San Primitivo. 1994 Factors influencing variation of test day milk yield, somatic cell count, fat, and protein in dairy sheep. J. Dairy Sci. 77:15371542 .

Gonzalo, C., J. A. Carriedo, E. Beneitez, M. T. Juárez, L. F. De la Fuente, and F. San Primitivo. 2006. Bulk tank total bacterial count in dairy sheep: Factors of variation and relationship with somatic cell count. J. Dairy Sci. 89:549-552.

Gonzalo, C., J. A. Carriedo, M. C. García-Jimeno, M. Pérez-Bilbao, and L. F. de la Fuente. 2010. Factors influencing variation of bulk milk antibiotic residue occurrence, somatic cell count, and total bacterial count in dairy sheep flocks. J. Dairy Sci. 93:15871595.

Gonzalo, C., and E. Ojeda. 1983. Comparación entre distintos métodos de ordeño mecánico y de éstos con el manual. Pages 204-215 in Proc. III Symp. Intl. Ordeño Mecánico Pequeños Rumiantes, Valladolid, Spain. Sever-Cuesta, ed. Valladolid, Spain.

Gootwine, E., B. Alef, and S. Gadeesh. 1980. Udder conformation and its heritability in the Assaf (Awassi $\times$ East Friesian) cross of dairy sheep in Israel. Ann. Genet. Sel. Anim. 12:9-13.

Gootwine, E., and H. Goot. 1996. Lamb and milk production of Awassi and East-Friesian sheep and their crosses under Mediterranean environment. Small Rumin. Res. 20:255-260.

Gootwine, E., and G. E. Pollott. 2000. Factors affecting milk production in improved Awassi dairy ewes. Anim. Sci. 71:607-615.

Guinee, T. P., E. O. Mulholland, J. Kelly, and D. J. O. Callaghan. 2007. Effect of protein-to-fat ratio of milk on the composition, manufacturing efficiency, and yield of Cheddar cheese. J. Dairy Sci. 90:110-123.

Instituto Nacional de Estadística (INE). 2010. Accessed Apr. 10, 2010. http://www.ine.es/inebmenu/mnu_agricultura.htm.

Institut National de la Recherche Agronomique (INRA). 2007. Alimentation des Bovins, Ovins et Caprins. Quæ, ed. Versailles, France.

Klinglmair, K., P. Winter, and W. Baumgartner. 2005. Studies on the use of Blu-Gard Spray in dairy sheep. Small Rumin. Res. $58: 157-162$.

Knight, T. W., and L. S. Gosling. 1995. Effects of milking frequency and machine-stripping on the yield and composition of milk from Poll Dorset ewes. N. Z. J. Agric. Res. 38:123-130.

Legarra, A., and E. Ugarte. 2005. Genetic parameters of udder traits, somatic cell score, and milk yield in Latxa sheep. J. Dairy Sci. $88: 2238-2245$.
Legaz, E., I. Álvarez, L. J. Royo, I. Fernández, J. P. Gutiérrez, and F. Goyache. 2008. Genetic relationships between Spanish Assaf (Assaf.E) and Spanish native dairy sheep breeds. Small Rumin. Res. 80:39-44.

Mantecón, A. R., P. Díez, B. Villadangos, Y. Martínez, and P. Lavín. 2009. Dairy sheep production systems at the central-north Spain: Effect of flock size. Opt. Médit. Sér. A 91:75-77.

MARM. 2010. Ministerio de Medioambiente y Medio Rural y Marino de España. Accessed Apr. 3, 2010. http://www.mapa.es/es/estadistica/pags/anuario/introduccion.htm.

Milán, M. J. J. Bartolomé, R. Quintanilla, M. D. García-Cachán, M. Espejo, P. L. Herráiz, J. M. Sánchez-Recio, and J. Piedrafita. 2006. Structural characterisation and typology of beef cattle farms of Spanish wooded rangelands (dehesas). Livest. Sci. 99:197-209.

Morin, E., C. Cassignol, and J. Fraysse. 2004. La Production de Lait de Brebis en France, Diversité des Systèmes d'Exploitation. Collection Résultats, Institut de l'Élevage, Paris, France.

Nahed, J., J. M. Castel, Y. Mena, and F. P. Caravaca. 2006. Appraisal of the sustainability of dairy goat systems in southern Spain according to their degree of intensification. Livest. Sci. 101:10-23.

NRC. 2008 Changes in the Sheep Industry in the United States: Making the Transition from Tradition. Natl. Acad. Sci., ed. The National Academies Press, Washington, DC.

Østerås, O., A. C. Whist, and L. Sølverød. 2008. The influence of iodine teat dipping and an external teat sealant in heifers on bacterial isolation from quarter milk culture obtained post-calving. Livest. Sci. 119:129-136.

Othmane, M. H., L. F. de la Fuente, J. A. Carriedo, and F. San Primitivo. 2002. Heritability and genetic correlations of test day milk yield and composition, individual laboratory cheese yield, and somatic cell count for dairy ewes. J. Dairy Sci. 85:2692-2698.

Pollott, G. E., and E. Gootwine. 2004. Reproductive performance and milk production of Assaf sheep in an intensive management system. J. Dairy Sci. 87:3690-3703.

Purroy, A., J. L. Martín, J. J. Jurado, and J. García. 1983. Estudio de diferentes rutinas de ordeño mecánico en ovejas de raza Churra. Pages 177-187 in Proc. III Symp. Intl. Ordeño Mecánico Pequeños Rumiantes, Valladolid, Spain. Sever-Cuesta, ed. Valladolid, Spain.

Raynal-Ljutovac, K., A. Pirisi, R. de Crémoux, and C. Gonzalo. 2007. Somatic cells of goat and sheep milk: Analytical, sanitary, productive and technological aspects. Small Rumin. Res. 68:126-144.

Riggio, V., D. O. Maizon, B. Portolano, H. Bovenhuis, and J. A. M. van Arendonk. 2009. Effect of somatic cell count level on functional longevity in Valle del Belice dairy sheep assessed using survival analysis. J. Dairy Sci. 92:6160-6166.

Sanna, S. R., S. Casu, G. Ruda, A. Carta, S. Ligios, and G. Molle. 2001. Comparison between native and "synthetic" sheep breeds for milk production in Sardinia. Livest. Prod. Sci. 71:11-16.

Thomas, D. L. 2004. Overview of the dairy sheep sector in Canada and the United States. Pages 6-14 in Proc. 10th Annual Great Lakes Dairy Sheep Symposium, Hudson, WI. Department of Animal Science, University of Wisconsin-Madison.

Toral, P. G., G. Hervás, P. Gómez-Cortés, P. Frutos, M. Juárez, and M. A. de la Fuente. 2010. Milk fatty acid profile and dairy sheep performance in response to diet supplementation with sunflower oil plus incremental levels of marine algae. J. Dairy Sci. 93:16551667.

Ugarte, E., R. Ruiz, D. Gabiña, and I. Beltrán. 2001. Impact of highyielding foreign breeds on the Spanish dairy sheep industry. Livest. Prod. Sci. 71:3-10. 